\title{
Investigation of anaerobic biodegradability of real compost leachate emphasis on biogas harvesting
}

\author{
H. Hashemi ${ }^{1}$ A. Ebrahimi ${ }^{2}$ A. Khodabakhshi ${ }^{3}$
}

Received: 9 September 2014/Revised: 14 March 2015/Accepted: 21 April 2015/Published online: 12 May 2015

(C) Islamic Azad University (IAU) 2015

\begin{abstract}
Anaerobic treatability of real compost leachate was assessed using laboratory-scale anaerobic sequencing batch reactor at mesophilic conditions. Interventional study was conducted at wide range of organic loading rate $0.93-25 \mathrm{~g} \mathrm{l}^{-1}$ day $^{-1}$ by varying hydraulic retention times 23 and $12 \mathrm{~h}$. Initial chemical oxygen demand (COD) was 1.85-25 $\mathrm{g} \mathrm{l}^{-1}$. $\mathrm{pH}$ variations; total, soluble (SCOD), readily biodegradable (rbCOD) chemical oxygen demand; volatile fatty acids degradation; biogas production; and methane fraction were considered in this study. The organic matter removal efficiencies were in the range of $76-81 \%$ depending on loading rates applied. The maximum volumetric methane production rate of $5.71 \mathrm{CH}_{4}$ $1^{-1}$ day $^{-1}$ was achieved at the loading rate of $19.65 \mathrm{~g} \mathrm{l}^{-1} \mathrm{day}^{-1}$. About $85 \%$ of removed organic matters during the biodegradation were converted to the methane. The results have shown that the anaerobic batch reactor could be an appealing option for changing compost leachate into the useable products such as biogas and other energy-rich compounds, which may play a serious role in meeting the world's ever-increasing energy requirements in the future.
\end{abstract}

A. Khodabakhshi

khodabakhshi16@gmail.com

1 Environmental Health Engineering, School of Health, Shiraz University of Medical Sciences, Shiraz, Iran

2 Environmental Sciences and Technology Research Center, Department of Environmental Health Engineering, Shahid Sadoughi University of Medical Sciences, Yazd, Iran

3 Environmental Health Engineering, School of Health, Shahrekord University of Medical Sciences, Shahrekord, Iran
Keywords Batch process - Compost liquid - Methane . Organic load

\section{Introduction}

Improper source separation of waste in developing countries like Iran leads to the production of considerable waste with high water content and various pollutants (Troschinetz and Mihelcic. 2009). Putrescible wastes as a raw material of compost consist of high water content, and water is also produced during biodegradation processes. This wastewater seeps out and forms what is known as leachate (Khalid et al. 2011). For example, Isfahan compost plant produces leachate at an average of about $40 \mathrm{~m}^{3}$ day $^{-1}$. Leachates are heavily polluted wastewaters with a complex composition containing microorganisms typically Bacillus, Citrobacter, Enterobacter, E. coli, Klebsiella, Nieseria, Pseudomonas, Shigella, Staphylococcus, Streptococcus and Vibrio (Obire and Aguda. 2002); dissolved organic matters; inorganic macrocomponents; heavy metals; and xenobiotic organic compounds with a foul odor (Safari et al. 2011). It leached from several points of compost facilities and viewed as a pollution source of soil, surface water and groundwater, on account of organic substrates and potential pathogens which pose a risk to the environment and public health if released without proper treatment (El-Fadel et al. 2003; Zhang et al. 2007). In spite of compost production, the management and effective treatment of compost leachate is worth paying attention. Compost leachate may be treated anaerobically, saving environment and converting the organic material partially to biogas (Bonmat et al. 2001). Even toxic compounds may be degraded anaerobically depending on the process applied. One prerequisite is that a feed waste contains a 
considerable amount of organic matter that is finally converted mainly to $\mathrm{CH}_{4}$ and $\mathrm{CO}_{2}$. At least $20 \%$ of energy used in the EU comes from renewable sources, and $10 \%$ of the fuels used in transport being biofuels (Karim et al. 2005). In this context, anaerobic digestion with biogas generation is a good answer to today's environmental challenges (Ghani and Idris. 2009). Indeed, anaerobic digestion with energy recovery produces less greenhouse gases than incineration or landfilling (Khalid et al. 2011). As a rule of thumb, wastes containing $<60 \%$ of volatile solids are rarely considered as substrates for anaerobic digestion. Therefore, with regard to the total solids content, the percentage of volatile solids, the $\mathrm{C}: \mathrm{N}$ ratio and the biodegradability, compost leachate can be used as suitable substrate for anaerobic digestion that generates useable biogas as a source of energy (Agdag and Sponza. 2005). Few studies have been conducted on the anaerobic digestion of compost leachate. Furthermore, most of those studies use synthetic leachate. Compost leachate and young landfill leachate normally contain high amounts of volatile fatty acids (VFAs). These readily biodegradable matters account for the bulk of the chemical oxygen demand (COD) of leachate, so the ratio of biological oxygen demand (BOD) to COD is relatively high (Nayono et al. 2010). The anaerobic treatment of young leachate in an anaerobic system allows the anaerobic stabilization to terminate which was initiated in the tip. Among the biological processes found in the scientific literature, ASBR have shown good removal efficiencies in pretreatment of municipal solid waste compost plant leachate (Amin et al. 2014). COD removal was as high as $85-90 \%$ for the whole sequential anaerobic-aerobic treatment process, while the COD removal efficiency in the anaerobic stage was only $60 \%$ (Palatsi et al. 2011). HRT of about 70 days would be needed to achieve $90 \%$ COD removal in a leachate containing in excess of about $150,000 \mathrm{mg} \mathrm{l}^{1}$ of COD for which relatively large reactors are required $(\mathrm{Oz}$ and Yarimtepe. 2014). Nevertheless, it has been claimed that the anaerobic digestion of leachate does not remove ammoniacal $\mathrm{N}$ at all (often up to $1000 \mathrm{mg} \mathrm{l}^{-1}$ ) and indeed is more likely to increase concentrations of this main contaminant of leachates. Sometimes, co-digestion of leachate and wastewater can be an attractive option for upgrading digestion efficiency, providing balance of nutrients and the synergy effect between organic substrates (Xiaofeng et al. 2014). According to the Bouallagui et al. (2009) research, during the digestion of fruit and vegetable waste, additions of abattoir wastewater or activated sludge could enhance biogas yields by 51.5 and $43.8 \%$, respectively. The added wastewater or sludge lowered carbon-nitrogen ratio and enhanced biogas yields (El-Mashad and Zhang 2010). The biogas produced through the anaerobic digestion of organic fraction of municipal solid waste comprised of $50-70$ vol \% $\mathrm{CH}_{4}, 30-50$ vol $\% \mathrm{CO}_{2}$ and trace volatile compounds that should be controlled and reduced to ultra-low levels in a gas-cleaning section (Mata-Alvarez et al. 2000; Khalid et al. 2011). This study will mainly focus on the real compost leachate COD removal and biogas production using ASBR process in Isfahan (Iran) during the period of June 2012 and March 2014.

\section{Materials and methods}

\section{Pilot setup}

The total volume of reactor was 21 with 0.51 filled with sludge, 11 was completed with the addition of pretreated leachate, and 0.51 was used as freeboard for biogas storage into the headspace. The laboratory-scale batch reactor consisted of a thermostated water bath glass container with a liquid working volume of 201 which was maintained a temperature of $37^{\circ} \mathrm{C}$. To obtain a homogeneous suspension, feeding was injected by one etatron pump through the bottom of the reactor. The reactor content was mixed with a vertical mixer inside the reactor. At the end of each cycle, mixer was stopped and after 1-h settling, and 11 of supernatant was withdrawn from decant valve. A detail of the ASBR reactor is presented in Fig. 1.

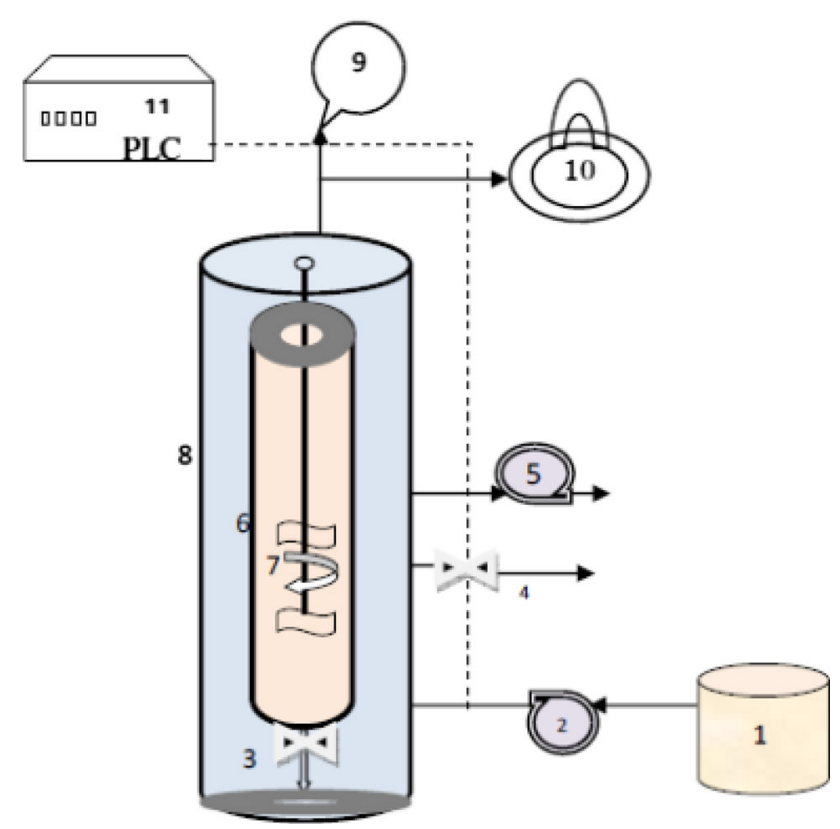

Fig. 1 Simplified schematic diagram of the ASBR pilot: 1 feeding tank, 2 injection pump, 3 sludge intake valve, 4 sampling valve, 5 decant valve, 6 ASBR, 7 mixer, 8 bath container water, 9 Tedlar bag, 10 gas meter, 11 PLC 


\section{ASBR start-up and operational pattern}

Experimental study was conducted at wide range of organic loading rate $\left(\mathrm{OLR}=0.93-25 \mathrm{~g} \mathrm{COD} l^{-1} \mathrm{day}^{-1}\right)$ by varying hydraulic retention times (HRT $=23$ and $12 \mathrm{~h}$ ) and initial COD of $1.85-25 \mathrm{~g} \mathrm{l}^{-1}$. Because of the seasonal biodegradability variations and acidic nature of the compost leachate, by using higher HRT and dilution of the influent, anaerobic reactor was adopted gradually. So there was no need for supplementation alkalinity. The reactor was operated with a 24-h cycle approximately consisting of fill (10 min of mixed fill), react (23-12 h), settle (1 h), and decant $(10 \mathrm{~min})$ phases. Partially granulated anaerobic sludge with a total VSS amount of $7500 \mathrm{mg} \mathrm{l}^{-1}$ was taken from the methanogenic digester of wastewater treatment plant in Isfahan (Iran) and used as seed in ASBR reactor. Sometimes, biomass loss was occurred due to influent shock that was replaced, using 0.51 acclimated sludge. In first runs, HRT and OLR were fixed. The influent rate was kept constant at $11 \mathrm{day}^{-1}$. After steady state, HRT was decreased and OLR was increased. Adaptation of microorganisms to the leachate and operating conditions was also pointed out along the consecutive batches.

\section{Experimental setup and analytical methods}

ASBR reactor was inoculated with 11 sludge from an anaerobic digester that operated at $35^{\circ} \mathrm{C}$. Washing of sludge with distilled water to remove coarse particles and then sieving with a pore diameter of $5 \mathrm{~mm}$ were performed. The sludge characteristics are given in Table 1.

Operational issues of the each cycle including $\mathrm{pH}$, total COD, rbCOD, SCOD (in filtered samples) and TSS were analyzed in accordance with standard methods twice a week. The $\mathrm{pH}$ was measured using a calibrated $\mathrm{pH}$ meter (Schott, Model GC 824). COD measurement was conducted based on Dichromate method (closed reflux, 5220C, colorimetric method) (APHA 2005). The floc/filtration method was used for measurement of the rbCOD concentration (Agdag and Sponza. 2005). The reactor was properly sealed to ensure anaerobic condition and to prevent gas leakage. After sealing the gas-tight lids on the reactors, the produced biogas in the ASBR was collected using 50-ml plastic bag, and the daily volume was read directly using the ELSTER wet-test gas meter, PVC model (Elster,

Table 1 Sludge characteristic was used to ASBR reactor
AMCO, Germany). Composition of the produced biogas was determined by gas chromatograph (Auto System Perkin Elmer, USA) that was equipped with a packed column (Perkin Elmer, $6^{\prime} \times 1.8^{\prime \prime}$ OD, 80/100, Mesh, USA) and a thermal conductivity detector (Perkin Elmer, USA). An inject temperature of $150{ }^{\circ} \mathrm{C}$ was applied, and the carrier gas was nitrogen operated with a flow rate of $20 \mathrm{ml} \mathrm{min}{ }^{-1}$ at $75{ }^{\circ} \mathrm{C}$. An Agilent technologies system consisting of a $5975{ }^{\circ} \mathrm{C}$ Inert MSD with a triple axis detector equipped with a 7890A gas chromatograph with a split/splitless injector was used for the quantification and confirmation of the VFA.

\section{Results and discussion}

\section{Feeding leachate characterization}

The mixture of leachate produced in different units of Isfahan compost plant (Receiving hall, Shredding, Press and Fermentation site) was obtained. Compost leachate was pretreated by anaerobic mixing baffled reactor (AMBR) to alleviate organic loading and solids, and after that, it was injected to the ASBR. Characteristics of the feed are presented in Table 2.

The leachate showed high $\mathrm{COD}$ and $\mathrm{BOD}_{5}$ concentrations. The $\mathrm{BOD}_{5} / \mathrm{COD}$ ratio (or biodegradability factor) varied between 0.28 and 0.38 , and all samples had a relatively high biodegradability index. Total suspended solids concentration was high due to the leachate being fed from the anaerobic reactor. The $\mathrm{pH}$ of the leachate samples was varying between 6.4 and 7.5. The leachate had a strong odor, probably due to a high content of volatile fatty acids. Also compost leachate contains different microbial communities.

\section{COD removal}

Figure 2 shows the removal efficiencies of COD, SCOD and rbCOD parameters in ASBR reactor at various OLRs. Influent COD, SCOD and rbCOD concentrations were in

Table 2 Results of the main feed leachate parameters analyzed

\begin{tabular}{llr}
\hline Parameter & Range & Mean \pm SD \\
\hline Total COD $(\mathrm{g} / \mathrm{l})$ & $1.85-25$ & $11.19 \pm 8.64$ \\
$\mathrm{SCOD}(\mathrm{g} / \mathrm{l})$ & $0.42-7.25$ & $3.12 \pm 2.45$ \\
$\mathrm{rbCOD}(\mathrm{g} / \mathrm{l})$ & $0.07-2.3$ & $0.88 \pm 0.86$ \\
$\mathrm{BOD}_{5} / \mathrm{COD}$ & $0.28-0.38$ & $0.33 \pm 0.03$ \\
$\mathrm{Ph}$ & $6.23-8$ & $7.38 \pm 0.42$ \\
$\mathrm{EC}(\mathrm{mS} / \mathrm{cm})$ & $2.13-20.68$ & $11.57 \pm 7.74$ \\
$\mathrm{TDS}(\mathrm{g} / \mathrm{l})$ & $1.49-11.02$ & $6.85 \pm 4.05$ \\
\hline
\end{tabular}

\begin{tabular}{lll}
\hline Parameter & Value & Unit \\
\hline TSS & 10,700 & $\mathrm{mg} / \mathrm{l}$ \\
VSS & 7950 & $\mathrm{mg} / \mathrm{l}$ \\
VSS/TSS & 0.74 & - \\
$\mathrm{pH}$ & 7.55 & - \\
\hline
\end{tabular}




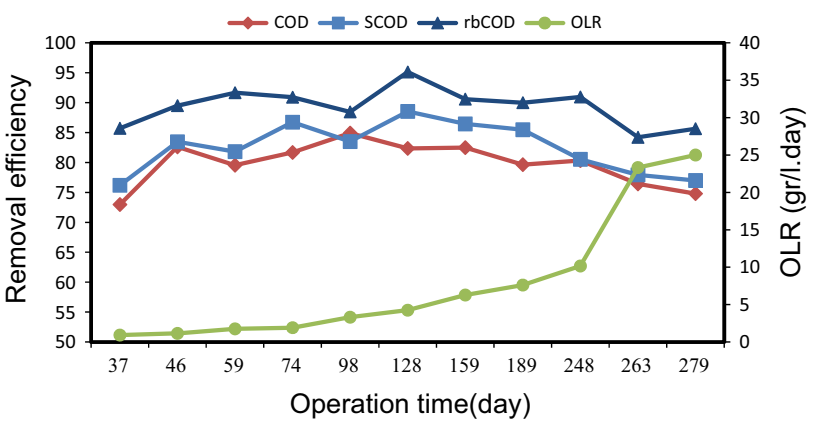

Fig. 2 Removal efficiency of COD, SCOD and rbCOD in ASBR reactor at different OLRs during the periods of operation

the ranges of $1.85-25,0.42-6.52$ and $0.07-2.3 \mathrm{~g} \mathrm{l}^{-1}$, respectively. In the effluent, these parameter concentrations were in the ranges of $0.4-6.3,0.1-2.4$ and $0.01-0.8 \mathrm{~g}^{-1}$, respectively. The effluent ranges of $\mathrm{BOD}_{5} / \mathrm{COD}$ ratio was 0.1-0.28. When HRT was decreased from 23 to $12 \mathrm{~h}$, the effluent concentrations of parameters were increased and $\mathrm{BOD}_{5} / \mathrm{COD}$ ratio was decreased. Total COD, SCOD and rbCOD removal efficiencies, respectively, of more than 80 , 81 and $90 \%$ were achieved at an OLR of $10.2 \mathrm{~g}$ $\mathrm{COD}^{-1} \mathrm{day}^{-1}$, and a gradual decrease in OLR of $25 \mathrm{~g}$ $\mathrm{COD}^{-1}$ day $^{-1}$ still gave COD, SCOD, rbCOD and $\mathrm{BOD}_{5}$ removal efficiencies of 75,63 and $80 \%$, respectively. Removal efficiency of rbCOD was higher than COD and SCOD. These parameters' removal efficiency was initially high and relatively stable but decreased when OLR was increased to $25 \mathrm{~g} \mathrm{COD}^{-1}$ day $^{-1}$. Average removal efficiency of COD, SCOD and rbCOD in HRT of $24 \mathrm{~h}$ was 81 , 84 and $91.3 \%$, respectively. But in HRT of $12 \mathrm{~h}$, it was decreased to 76,78 and $85 \%$, respectively.

Some studies revealed good performances of anaerobic sequencing batch reactors. Typical values of 80-90\% and nearly $55 \%$ COD removals were reached in anaerobic laboratory-scale tank at $35^{\circ} \mathrm{C}$ and ambient temperature, respectively (Abbas et al. 2009).

\section{VFA profile}

VFAs effluent concentration was increased to $0.1 \mathrm{~g} \mathrm{l}^{-1}$ when OLR increased to $10.2 \mathrm{~g} \mathrm{COD}^{-1}$ day $^{-1}$. Additionally, when removal efficiency of SCOD was decreased to $77 \%$, the effluent concentration of VFAs was increased to $0.34 \mathrm{~g} \mathrm{l}^{-1}$. The VFA removal efficiency was high throughout all testing OLRs, in excess of $85 \%$ (Fig. 3). The maximum specific removal rate for VFA-rich wastes such as municipal landfill leachate can be in the range of 4-5 g COD/g VSS d (Hashemi et al. 2015). In Bae et al. study (2010), the level of propionate in the final effluent was lower than $900 \mathrm{mg} \mathrm{COD}{ }^{-1}$, indicating relatively good performance of the anaerobic process.

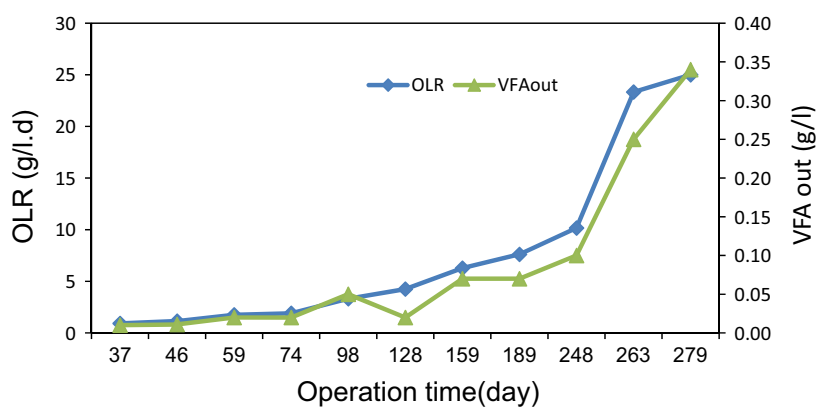

Fig. 3 Effluent mixture VFA concentration in ASBR reactor during the time

\section{Biogas production}

The study was conducted at eleven OLRs from 1.04 to $19.65 \mathrm{~g} \mathrm{COD}^{-1}$ day $^{-1}$ in 280 days. The ability of ASBR process in biogas production at various OLRs and its efficiency in removal of COD, SCOD, rbCOD and VFAs were evaluated. At any microorganism concentration, the food-microorganism ratio $(\mathrm{F} / \mathrm{M})$ is high right after when the feed cycle is completed. This provides a high driving force for metabolic activity and high overall rates of waste conversion to biogas. Up to the end of the react cycle, the substrate concentration is minimum, providing low $\mathrm{F} / \mathrm{M}$ ratio for biomass flocculation. The biogas produced during the anaerobic degradation is a valuable resource of energy (Pages-Diaz et al. 2014). The exact expectation of the producible biogas amount and its methane content are one of the most important aspects of an anaerobic reactor. The quality and quantity of the biogas have special importance. The chemical compositions of a leachate determine the potential biogas yields, as well as the gas composition. The biogas production versus OLRs is shown in Fig. 4.

In reactor start-up phase, a lag can be observed in biogas production. Then, during the subsequent batches, the lag becomes less and less pronounced as the reaction becomes quicker. This phenomenon can be attributed to an adaptation of the microorganisms to the waste and to the

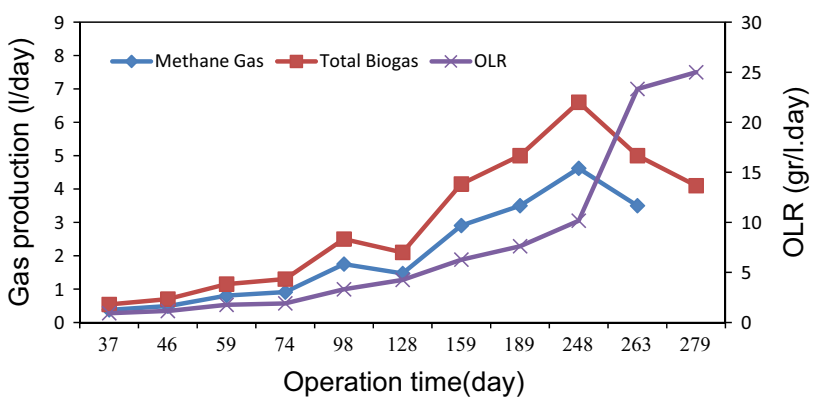

Fig. 4 Biogas production at different OLRs in ASBR in the operation times 
conditions of the experiment. The biogas produced was 0.551 when the OLR was $1.04 \mathrm{~g} \mathrm{COD} \mathrm{l}^{-1} \mathrm{day}^{-1}$, and after a gradual increase to an OLR of $10.08 \mathrm{~g} \mathrm{COD}^{-1}$ day $^{-1}$, it still gave 5.681 .

The range of the methane content of biogas was between 55 and $65 \%$, which is comparable with the reported range of $67 \pm 81 \%$ for the leachate. When the OLR was $1.04 \mathrm{~g}$ $\mathrm{COD}^{-1}$ day $^{-1}$, the produced methane was 0.31 , and when gradually increased to an OLR of $10.08 \mathrm{~g}$ $\mathrm{COD}^{-1}$ day $^{-1}$, it still gave 3.121 . Methane production for reactor was in the range of $0.29-0.421 \mathrm{CH}_{4} / \mathrm{g}$ COD removed. When the OLR was $10.08 \mathrm{~g} \mathrm{COD}^{-1}$ day $^{-1}$ and HRT was $23 \mathrm{~h}$, the biogas production rate was $5.68 \mathrm{l}$, but in HRT of $12 \mathrm{~h}$ and OLR of $19.65 \mathrm{~g} \mathrm{COD} \mathrm{l}^{-1} \mathrm{day}^{-1}$, the biogas production rate was 6.651 .

In similar study, about $83 \%$ of COD removed is converted to methane. Also each $\mathrm{g}$ of VSS in ASBR reactors is capable of converting a daily maximum of $1.06 \mathrm{~g}$ of COD to the methane (Karimi et al. 2011).

\section{Conclusion}

Compost leachate may be treated anaerobically, saving environment and converting the organic material partially to biogas energy.

The COD removal efficiencies were in the range of $76-81 \%$ depending on loading rates applied. The exploitation of produced biogas during anaerobic digestion is an interesting option to achieve a high fuel-to-power conversion rate, even for small-size generators. The maximum volumetric methane production rate (VMPR) of 5.71 $\mathrm{CH}_{4} \mathrm{l}^{-1}$ day $^{-1}$ was achieved at the OLR of $19.65 \mathrm{~g}$ $\mathrm{COD}^{-1}$ day $^{-1}$. About $85 \%$ of COD removed during the treatment was converted to methane. The results have shown that the ASBR reactor could be an appealing option for changing compost leachate into biogas, which may play a serious role in meeting the world's ever-increasing energy requirements in the future.

\section{References}

Abbas AA, Jingsong G, Ping LZ, Ya PY, Al-Rekabi WS (2009) Review on Landfill Leachate Treatments. J Appl Sci Res 5(5):534-545

Agdag O, Sponza D (2005) Anaerobic/aerobic treatment of municipal landfill leachate in sequential two-stage up-flow anaerobic sludge blanket reactor (UASB)/completely stirred tank reactor (CSTR) systems. Process Biochem 40(2):895-902

Amin MM, Hashemi H, Bina B, Ebrahimi A, Pourzamani HR, Ebrahimi A (2014) Environmental pollutants removal from compost leachate using anaerobic biological treatment process. Int J Health Syst Disaster Manag 2(3):136-140
APHA, AWWA, WEF (2005) Standard methods for the examination of water and wastewater, 21st edn. American Public Health Association, Washington

Bae JH, Lee EY, Heo AH, Kim HK, Kim JH, Park SK (2010) Treatment of garbage leachate with a pilot scale two-phase anaerobic digestion with ultra filtration. In: Proceedings of the Venice, third international symposium on energy from biomass and waste, Venice, Italy: pp 8-11

Bonmat A, Flotats X, Mateu L, Campos E (2001) Study of thermal hydrolysis as a pretreatment to mesophilic anaerobic digestion of pig slurry. Water Sci Technol 44(4):109-116

Bouallagui H, Lahdheb H, Ben Romdan E, Rachdi B, Hamdi M (2009) Improvement of fruit and vegetable waste anaerobic digestion performance and stability with co-substrates addition. J Environ Manag 90:1844-1849

El-Fadel M, Bou-Zeid E, Chahine W (2003) Landfill evolution and treatability assessment of high-strength leachate from msw with high organic and moisture content. Int $\mathrm{J}$ Environ Stud 60(6):603-615

El-Mashad HM, Zhang RH (2010) Biogas production from codigestion of dairy manure and food waste. Bioresour Technol 101:4021-4028

Ghani W, Idris A (2009) Preliminary study on biogas production of biogas from municipal solid waste (MSW) leachate. J Eng Sci Technol 4(4):374-380

Hashemi H, Hajizadeh Y, Amin MM, Bina B, Ebrahimi A, Khodabakhshi A, Ebrahimi A, Pourzamani HR (2015) Macropollutants removal from compost leachate using membrane separation process. Desalin Water Treat 53:1-6

Karim K, Hoffmann R, Thomas K, Al-Dahhan M (2005) Anaerobic digestion of animal waste: effect of mode of mixing. Water Res 39(15):3597-3606

Karimi B, Ehrampoush MH, Mokhtari M, Ebrahimi A (2011) Leachate treatment using wet air oxidation processes. J Environ Health Sci Eng Iran 4(1):23-34

Khalid A, Arshad M, Anjum M, Mahmood T, Dawson L (2011) The anaerobic digestion of solid organic waste. Waste Manag 31(8):1737-1744

Mata-Alvarez J, Mace S, Llabres P (2000) Anaerobic digestion of organic solid wastes. An overview of research achievements and perspectives. Bioresour Technol 74:3-16

Nayono SE, Winter J, Gallert C (2010) Anaerobic digestion of pressed off leachate from the organic fraction of municipal solid waste. Waste Manag 30(10):1828-1833

Obire O, Aguda M (2002) Bacterial community of leachate from a waste-dump and an adjacent stream. J Appl Sci Environ Manag 6(2):71-75

Oz N, Yarimtepe CC (2014) Ultrasound assisted biogas production from landfill leachate. Waste Manag 34(7):1165-1170

Pages-Diaz J, Pereda-Reyes I, Taherzadeh MJ, Sarvari-Horvath I, Lundin M (2014) Anaerobic co-digestion of solid slaughterhouse wastes with agro-residues: synergistic and antagonistic interactions determined in batch digestion assays. Chem Eng J 245:89-98

Palatsi J, Viñas M, Guivernau M, Fernandez B, Flotats X (2011) Anaerobic digestion of slaughterhouse waste: main process limitations and microbial community interactions. Bioresour Technol 102(3):2219-2227

Safari E, Jalili Ghazizade M, Shokouh A, Nabi Bidhendi GhR (2011) Anaerobic removal of cod from high strength fresh and partially stabilized leachates and application of multi stage kinetic model. Int J Environ Res 5(2):255-270

Troschinetz AM, Mihelcic JR (2009) Sustainable recycling of municipal solid waste in developing countries. Waste Manag 29(2):915-923 
Xiaofeng L, Shuangyan Z, Delai Z, Jingping Z, Li L (2014) Anaerobic co-digestion of food waste and landfill leachate in single-phase batch reactors. Waste Manag 34:2278-2284

Zhang C, Zeng G, Yuan L, Yu J, Li J, Huang G, Xi B, Liu H (2007) Aerobic degradation of bisphenol $\mathrm{A}$ by Achromobacter xylosoxidans strain B-16 isolated from compost leachate of municipal solid waste. Chemosphere 68:181-190 